Egyptian Veterinary Medical Society of Parasitology Journal

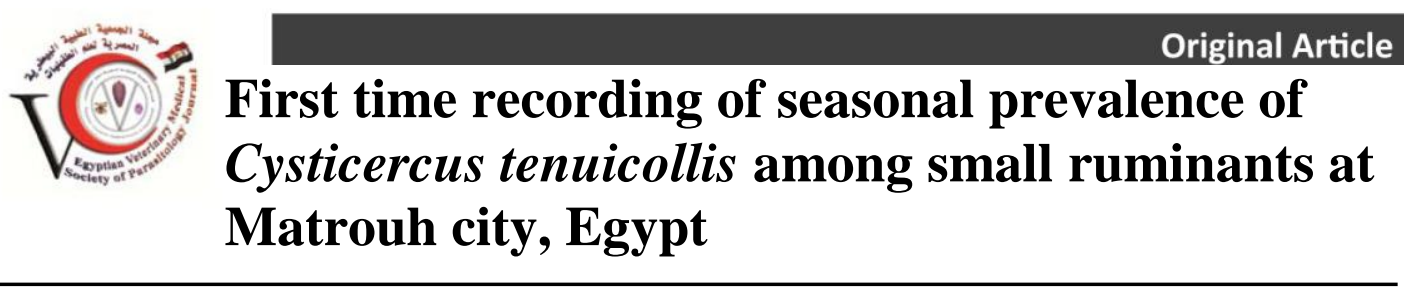

Felefl1, W.I. and Laban2, N.E

${ }^{1}$ Department of Parasitology, Faculty of Veterinary Medicine Matrouh University

2 Department of Parasitology, Faculty of Veterinary Medicine Abis, Alexandria, Egypt Post Code: 21944

*Author of correspondence: nadia.ebrahim@alexu.edu.eg

\begin{abstract}
As first time recording, the purpose of this study was to estimate the monthly and seasonal prevalence of Cysticercus tenuicollis, (C. tenuicollis); identify factors that can influence its occurrence and to assess the distribution of the cyst in the visceral organs of sheep and goats slaughtered at Matrouh city abattoir in Allam Elrom- Marsa Matrouh governorate, Egypt. A total of 4216 animals (1400 sheep and 2816 goats) were examined during the period from 28 November 2019 till 27 November 2020 at the abattoir. The overall prevalence of C. tenuicollis was $17.7 \%$, and $21 \%$ and $11 \%$ in goats and sheep respectively. There was significant variation in the prevalence of $C$. tenuicollis between sheep and goats and other animal species was considered as a risk factor as goat had a 2-time chance of infection more than sheep (X2 $=64.501 \mathrm{a}$ and $\mathrm{P}=0.000$ ). There was no significant variation in the prevalence of $C$. tenuicollis between male and female. The cyst was found most frequently attached to omentum, liver, lung, and diaphragm in both sheep and goats.

Concerning seasonal dynamics of $C$. tenuicollis was found to increase during Autumn season (19.1\%) to reach its maximum during Winter (20.7\%) and started to decrease during Spring $(17.1 \%)$ to be the lowest in Summer season (15\%).

In conclusion, the presence of $C$. tenuicollis at a higher prevalence and the consequent effect on small ruminant signify the need for the control of stray dog population, deworming of dogs, and avoidance of backyard slaughter and proper disposal of infected viscera to curtail the problem.
\end{abstract}

Key words: Prevalence, Cysticercus tenuicollis, sheep and goats. - Marsa Matrouh.
Introduction Taenia hydatigena is an adult parasite of dogs with the metacestode (C.tenuicollis) stage residing in ruminants and pigs. The metacestode infection due to C.tenuicollis is important because it causes huge economic losses due to condemnation of infected offal or meat 
(Flisser et al. 1982; Eckert et al., 1984; Thompson and Lymbery 1995). Additionally, the cysticerci of T. hydatigena are responsible for production losses and mortality in livestock (Singh et al., 2013). The meat produced by sheep and goats were about 135,000 tons in 2010 (FAO, 2015). The cyst is found attached to the omentum, liver, peritoneum, mesentery, diaphragm, pelvic cavity, lung (Mekuria et al., 2013), Migration of cysticerci can lead to formation of hemorrhagic and fibrotic tracts, serofibrinous peritonitis in the liver (Soulsby 1982; Blazek et al., 1985) with heavy infections leading to traumatic hepatitis and death in young lambs (Soulsby, 1982). The cyst is round with a glowing wall. It estimates suggesting that E. granulosus has about $1 / 100^{\text {th }}$ and $1 / 30^{\text {th }}$ the biotic potential of $T$. hydatigena and T. ovis (WHO and OIE 2001).

\section{Aim of the study}

In Egypt, $C$. tenuicollis was detected in slaughtered sheep and goat in Sharkia (ElAzazy and Fayek, 1990), Aswan (Dyab et al., 2017), AlGharbia (Sultan et al., 2010), Benisouf (El-Dakhly et al., 2012), AlDakahlia (Abu-Elwafa et al.,2009 and contains a scolex, neck, and a fluidfilled sac. When carefully squeezed the head and neck emerged in front of the bladder, AbouLaila, et al., (2020). The presence of the cyst leads to the rejection of affected organs and subsequent economic losses (Scala et al., 2016). Diagnosis in livestock is usually based on the host and the location of them metacestode when identified at meat inspection or necropsy (WHO and OIE, 2001). Size of the cysts (C.tenuicollis) varies from one $\mathrm{cm}$ up to $6-7 \mathrm{~cm}$, and the scolex has a long neck. They are found attached to the omentum, mesentery and occasionally on the liver surface, particularly of sheep (OIE, 2008). The biotic potential of $T$. hydatigena is high and

El-Alfy et al., 2017), and Sohage and Qina (Omar et al., 2016).

The infection rate of $C$. tenuicollis in sheep and goat at Matrouh city, Egypt and its prevalence and morphological characterization were recorded for the first time.

\section{Materials and methods}

2.1. Animals and the study area (N" 13 ' $1231^{\circ} \& \mathrm{E}^{\prime \prime} 14{ }^{\prime} 14027^{\circ}$ ) 
All goat and sheep were slaughtered in general Matrouh city abattoir in Allam Elrom- Marsa Matrouh governorate, Egypt (N" 13' $1231^{\circ} \&$ E” 14' 14 027º 1400 sheep and 2816 goat (total of 4216) were examined for the presence of C. tenuicollis in the period from 28 November 2019 till 27 November 2020.

\subsection{Collection of cysts and the laboratory examinations}

All goat and sheep were examined by naked eyes for all carcasses parts to fine C.tenuicollis cyst then daily were collected the larval stage cysts, the cysts were collected in cooled bags contain Formalin $5 \%$ and transported to the laboratory of Parasitology at the Faculty of Veterinary Medicine, Alexandria University for the further parasitological examinations. Samples were fixed in $10 \%$ buffered formalin, stained with alum-carmine and mounted on glass slides for the morphological identifications (Kaufmann, 2013; Soulsby and Mönnig, 1982). Measurements and identification of the collected cysts were performed (Pritchard and Kruse, 1982). Also, the age of the examined animals was arranged into two groups, more than 3 years and less than 3 years.

\subsection{Data collection}

Data was collected through:

\subsubsection{Questionnaire}

A questionnaire was designed to collect the data it included the animal types, animal sex, animal age, daily recorded of number of the total small ruminants were infected out of the total number of small ruminant's animal were slaughtered in general Matrouh city abattoir.

\subsubsection{Laboratory study}

Laboratory examination using light microscope $10 \mathrm{x}$ to predict and confirm the C.tenuicollis scolex its contains (sucker, hooks, vitality fluid).

\subsection{Statistical analysis}

After a complete collection of the data, the data enrolled in statistical analysis using SPSS Version 24. The Chi-square test was used to detect the difference between different age and sex groups. The results were considered significant at $\mathrm{P} \leq .05$.

\section{Results}

\subsection{Infection rate}

The total infection rate with C.tenuicollis in sheep and goat was $17.7 \%$, (Table 1).

The infection rate in goat was $21 \%$ and in sheep was $11 \%$. Animal species was considered as a risk factor as goat had a 2time chance of infection more than sheep $(\mathrm{X} 2=64.501 \mathrm{a}$ and $\mathrm{P}=0.000)($ Table 2). 
The infection rate in male $(17.8 \%)$ was close to female $(17.3 \%)$ groups (Table 1) nonetheless, there was no critical contrast between the two groups (X2 $=0.196 \mathrm{a}$ and $\mathrm{P}=0.658$ ) (Table 3).

The distribution of the C.tenuicollis in slaughtered sheep and goat was 64 $(9.11 \%)$ in the liver, $647(86.72 \%)$ mesenteric membrane, 28 (3.75\%) liver and mesentery, 1 (0.14\%) lung, 1 (0.14\%) liver, mesentery and large intestine and 1 $(0.14 \%)$ for diaphragm (Table 4$)$.

\subsection{Prevalence of the cyst}

The Monthly prevalence of C.tenuicollis in the infected animals was shown in the (Table 5) the highest infection was noticed during December, January and February (26.9\%,23.1\% and 20.4\%) followed by May and June (19.8\% and 19. 1\%). October show a moderate level of infection with $16.8 \%$.

The low infection rate was observed in July, August and September (15.8\%, $15.3 \%$ and 14.3\%). April recorded the lowest infection rate by $13.5 \%$.

Seasonal dynamics of C.tenuicollis (Table 6) was found to increase during Autumn season $(19.1 \%)$ to reach its maximum during Winter (20.7\%) and started to decrease during Spring (17.1\%) to be the lowest in Summer season (15\%).

\subsection{Cyst habitat}

The omentum (mesentery) had the highest infection frequency between the organs in this study (Fig.2). $86.72 \%$ followed by liver $9.11 \%$ (Fig. 3) then liver and omentum by $3.75 \%$ (Fig. 1).

\subsection{Cyst structure}

The results showed that the external cyst wall was semi-transparent, white in color, some with yellowish. The wall of the bladder was transparent, faint and contained clear water fluid. The head which appeared as a white dot when carefully squeezed the head and neck emerged in front of the bladder Fig. (5). The fluid is clear, transparent and fills the cyst cavity. The present results showed that the size of the cysts was different between slaughter sheep and goats, ranging between small cyst $2-3.5 \mathrm{~cm}$ Fig. (5) and large cyst $6.5 \mathrm{~cm}$ in diameter.

\section{Discussion}

Infections of sheep and goat with larval stages of $T$. hydatigena is important because it causes economic losses due to condemnation of infected organs and carcasses (Bekele et al. 1992). Our study showed high prevalence $17.7 \%$ of these parasites whose occurrence adds to the economic losses due to presence of C.tenuicollis. However, although massive 
infections with these cysts can cause severe disease and mortality in sheep (Gånheim et al,.1998), there are few indications that latent cysticercosis has obvious effects on the productivity of sheep and goats.

In our study areas, dogs are kept by the animal owners, and believed that the dogs are useful for the community in preventing predators from their livestock. In the area, especially in rural, treating dogs for parasitic diseases is not practiced. Backyard slaughter of small ruminants and disposal of viscera and trimmings on open field is common. All these are very important for the life cycle to continue between the final and intermediate hosts.

\subsection{Infection rate}

The present study of the prevalence of C. tenuicollis found the infection rate to be the highest in goat $(21 \%)$, compared with sheep $(11 \%)$. The rate infection of goat was higher than that of sheep because most sheep develop protective immunity early in life and this immunity regulate the parasite population, while goat develops the immunity more slowly (Pathak and Gaur 1982).

These results within the range recorded by Omar et al., (2016), they reported a mean prevalence of $C$. tenuicollis in goat (19\%) and in sheep $(16 \%)$ in Upper Egypt, El-Azazy and Fayek (1990) who reported $26.4 \%$ in goat in Al-Sharkia, Egypt, and Aswan, Egypt 13.3\% in sheep Dyab et al., (2017). The obtained results were lower than that recorded by Aboulila et al., (2020) (18\%) in sheep in Minoufiya governorate, Egypt and $20 \%$ in sheep Abu-Elwafa et al., (2009). But infection rate was higher than those from Benisuf, Egypt 1.6\% in sheep El-Dakhly et al., (2012).

Our results were with the same range with Samuel and Zewde (2010) with prevalence of $18.04 \%$ and $12.87 \%$ in goats and sheep in central Ethiopia, respectively; Iran $12.87 \%$ in sheep Radfar et al.,(2005) and lower than study investigated in Mbeya district; Tanzania Braae et al., (2015) who recorded prevalence of $C$. tenuicollis in goats and sheep with $45.7 \%$ and $51.9 \%$, respectively; also, study from eastern Ethiopia which reported $79 \%$ in sheep and $53 \%$ in goat by Sissay et al., (2008), and $35.41 \%$ in goat and $32.5 \%$ in sheep from Iraq (Haddawee et al.,2018). But, it was found that our results were higher than that obtained from Palestine 2.2\% in sheep by Adwan et al., (2018). These variations in the prevalence mainly accounted to the grazing behavior and management system prevailing in the local areas (Senlik, 2008) and to high contamination of the environments. 
The results reveal that males had a higher infection rate than females, but nonsignificantly different (p) values were 0.960 (0.801-1.151) which revealed no effect of sex on the prevalence of the disease among the examined sheep and goat.

\subsection{Cyst habitat}

The omentum (Mesentery) had the highest infection frequency between the organs in the examined carcasses $(86.72 \%)$ followed by liver $(9.11 \%)$.

This is may be due to the presence of large amount of lipid, carbohydrates and other essential elements which absorbed by the parasite, so that, C.tenuicollis prefer omentum, as organ of supplying essential elements for their nourishment. The least infection rate was recorded in lungs and diaphragm $(0.14 \%)$.

These results in agreeing with (AbuElwafa et al., 2009, Braae et al., 2015; Dyab et al., 2017; Omar et al., 2016; Radfar et al., 2005, Samuel and Zewde (2010) and Senlik (2008) they reported that omentum is the predominant predilection sites for $C$. tenuicollis. While liver was the predilection site in several previous studies (Mekuria et al., 2013 and Wondimu et al., 2011).

\subsection{Prevalence of the cyst}

Increasing of $C$. tenuicollis during Winter $20.7 \%$ followed by Autumn season 19.1\% being identical to Pathak and Guar, 1982; increased in rainy seasons, El-Masry, 1986; increased in Autumn and within range with Abu-Elwafa et al., 2009, who detected high prevalence in Autumn followed by Winter. While the result disagreed with El-Alfy, et al., 2017 decided that Spring was the highest prevalence $(28.26 \%)$.

In conclusion, this study presented the infection rate, monthly prevalence, and cyst habitat of $C$. tenuicollis in sheep and goat, from Matrouh city, northwestern of Egypt.

Therefore, the following recommendations should be taken in consideration while rearing sheep:

(1) Sheep and goat stocks must be reared away from dogs (the final host of dog`s Taeniids) in order to prevent metacestode infections with subsequent avoidance of economic losses especially these larval stages are usually diagnosed after slaughtering, at meat inspection.

(2) In this regard, we have to emphasize the important role of meat inspection to offer a healthy meat for human consumption, free from public health hazards, especially in the absence of specific treatments of metacestode infections. 


\section{Ethical statement}

No experiments were conducted on the experimental animals in this study.

\section{Declaration of Competing Interest}

No conflict of interest
The authors would like to acknowledge. We thank Walid eltarras, Ahmed Aziz and Mohamed Elmassry (Veterinarians) for their excellent technical assistances and the slaughterhouse personnel of Allam Elrom- Marsa Matrouh for their positive cooperation during this study.

Acknowledgements

(Table 1): Total infection rate with Cysticercus tenuicollis in the examined animals.

\begin{tabular}{|c|c|c|c|c|c|}
\hline \multicolumn{2}{|c|}{ Non-infected animals } & \multicolumn{2}{|c|}{ Infected animals } & \multicolumn{2}{c|}{ Total } \\
\hline No. & $\%$ & No. & $\%$ & No. & $\%$ \\
\hline 3470 & 82.3 & 746 & 17.7 & 4216 & 100 \\
\hline
\end{tabular}

(Table 2): Total infection rate and risk factors associated with Cysticercus tenuicollis infection in sheep and goats.

\begin{tabular}{|c|c|c|c|c|c|}
\hline \multirow{2}{*}{$\begin{array}{l}\text { Type of } \\
\text { carcasses }\end{array}$} & \multicolumn{2}{|c|}{ Cyst infection } & \multirow{2}{*}{ Total } & $\mathbf{X} 2$ & \multirow{2}{*}{$\begin{array}{c}\text { Odds } \\
\text { ratio }\end{array}$} \\
\hline & $\begin{array}{c}\text { Non- } \\
\text { infected }\end{array}$ & infected & & $\mathbf{P}$ & \\
\hline Goat & $\begin{array}{l}2224 \\
79.0 \%\end{array}$ & $\begin{array}{l}592 \\
21>0 \%\end{array}$ & $\begin{array}{l}2816 \\
100.0 \%\end{array}$ & $64.501 \mathrm{a}$ & \multirow{3}{*}{$\begin{array}{c}0.464 \\
(0384- \\
0.562)\end{array}$} \\
\hline Sheep & $\begin{array}{l}1246 \\
89.0 \%\end{array}$ & $\begin{array}{l}154 \\
11.0 \%\end{array}$ & $\begin{array}{l}1400 \\
100.0 \%\end{array}$ & $0.00 *$ & \\
\hline Total & $\begin{array}{l}3470 \\
82.3 \%\end{array}$ & $\begin{array}{l}746 \\
17.7 \%\end{array}$ & $\begin{array}{l}4216 \\
100.0 \%\end{array}$ & & \\
\hline
\end{tabular}

(Table 3): Prevalence of Cysticercus tenuicollis in relation to sex of slaughtered animals.

\begin{tabular}{|c|c|c|c|c|c|}
\hline \multirow[b]{2}{*}{ Animal sex } & \multicolumn{2}{|c|}{ Animal cyst infection } & \multirow[b]{2}{*}{ Total } & \multirow{2}{*}{$\frac{\mathrm{X} 2}{\mathrm{P}}$} & \multirow[b]{2}{*}{ Odds Ratio } \\
\hline & $\begin{array}{c}\text { Non- } \\
\text { infected }\end{array}$ & Infected & & & \\
\hline \multirow[t]{2}{*}{ Male } & 2559 & 556 & 3115 & & \multirow{6}{*}{$\begin{array}{c}0.960 \\
(0.801- \\
1.151)\end{array}$} \\
\hline & $82.2 \%$ & $17.8 \%$ & $100.0 \%$ & $0.196 a$ & \\
\hline \multirow[t]{2}{*}{ Female } & 911 & 190 & 1101 & 0.658 & \\
\hline & $82.7 \%$ & $17.3 \%$ & $100.0 \%$ & & \\
\hline \multirow[t]{2}{*}{ Total } & 3470 & 746 & 4216 & & \\
\hline & $82.3 \%$ & $17.7 \%$ & $100.0 \%$ & & \\
\hline
\end{tabular}

(Table 4): Distribution of Cysticercus tenuicollis in the organs of infected animals. 


\begin{tabular}{|l|c|c|}
\hline \multicolumn{1}{|c|}{ Cyst habitat } & Frequency & \% \\
\hline Liver & 68 & 9.11 \\
\hline Mesenteric membrane & 647 & 86.72 \\
\hline Liver+ mesenteric & 28 & 3.75 \\
\hline Lung & 1 & 0.14 \\
\hline Liver, mesenteric, large intestine & 1 & 0.14 \\
\hline Diaphragm & 1 & 0.14 \\
\hline Total & 746 & 100.0 \\
\hline
\end{tabular}

(Table 5): Monthly prevalence of Cysticercus tenuicollis in the infected animals.

\begin{tabular}{|c|c|c|c|c|c|}
\hline \multirow[b]{2}{*}{ Month } & \multicolumn{2}{|c|}{ Animal cyst infection } & \multirow[b]{2}{*}{ Total } & \multirow{2}{*}{$\frac{\mathbf{X} 2}{\mathbf{P}}$} & \multirow[b]{2}{*}{ Odds ratio } \\
\hline & $\begin{array}{c}\text { Non- } \\
\text { infected }\end{array}$ & infected & & & \\
\hline \multirow{2}{*}{ November } & 230 & 41 & 271 & $40.606 a$ & $0.868(0.562-1.340$ \\
\hline & $84.9 \%$ & $15.1 \%$ & $100.0 \%$ & & \\
\hline \multirow{2}{*}{ December } & 223 & 82 & 305 & 0.000 & $1.784(1.223-2.603)$ \\
\hline & $73.1 \%$ & $26.9 \%$ & $100.0 \%$ & & \\
\hline \multirow{2}{*}{ January } & 267 & 80 & 347 & & $1.464(1.006-2.131)$ \\
\hline & $76.9 \%$ & $23.1 \%$ & $100.0 \%$ & & \\
\hline \multirow{2}{*}{ February } & 257 & 66 & 323 & & $1.27(0.861-1.875)$ \\
\hline & $79.6 \%$ & $20.4 \%$ & $100.0 \%$ & & \\
\hline \multirow{2}{*}{ March } & 220 & 45 & 265 & & $1.019(0.666-1.56)$ \\
\hline & $83.0 \%$ & $17.0 \%$ & $100.0 \%$ & & \\
\hline \multirow{2}{*}{ April } & 345 & 54 & 399 & & $0.787(0.527-1.175)$ \\
\hline & $86.5 \%$ & $13.5 \%$ & $100.0 \%$ & & \\
\hline \multirow{2}{*}{ May } & 255 & 63 & 318 & & $1.25(0.843-1.853)$ \\
\hline & $80.2 \%$ & $19.8 \%$ & $100.0 \%$ & & \\
\hline \multirow{2}{*}{ June } & 178 & 42 & 220 & & $1.167(0.754-1.808)$ \\
\hline & $80.9 \%$ & $19.1 \%$ & $100.0 \%$ & & \\
\hline \multirow{2}{*}{ July } & 417 & 78 & 495 & & $0.974(0.672-1.411)$ \\
\hline & $84.2 \%$ & $15.8 \%$ & $100.0 \%$ & & \\
\hline \multirow{2}{*}{ August } & 365 & 66 & 431 & & $0.998(0.676-1.472)$ \\
\hline & $84.7 \%$ & $15.3 \%$ & $100.0 \%$ & & \\
\hline \multirow{2}{*}{ September } & 420 & 70 & 490 & & $0.917(0.626-1.344)$ \\
\hline & $85.7 \%$ & $14.3 \%$ & $100.0 \%$ & & \\
\hline \multirow{2}{*}{ October } & 293 & 59 & 352 & & $1.019(0.666-1.56)$ \\
\hline & $83.2 \%$ & $16.8 \%$ & $100.0 \%$ & & \\
\hline \multirow{2}{*}{ Total } & 3470 & 746 & 4216 & & \\
\hline & $82.3 \%$ & $17.7 \%$ & $100.0 \%$ & & \\
\hline
\end{tabular}


(Table 6): Seasonal prevalence of Cysticercus tenuicollis in the infected animals.

\begin{tabular}{|c|c|c|c|c|c|}
\hline \multirow[b]{2}{*}{ season } & \multicolumn{2}{|c|}{ Animal cyst infection } & \multirow[b]{2}{*}{ total } & \multirow{2}{*}{$\begin{array}{c}\mathbf{X} 2 \\
\mathbf{P}\end{array}$} & \multirow[b]{2}{*}{ Odds ratio } \\
\hline & non-infected & infected & & & \\
\hline Autumn & $765(80.9 \%)$ & $181(19.1 \%)$ & 946 & & $1.343(1.078-1.674)$ \\
\hline Winter & $767(79.3 \%)$ & $200(20.7 \%)$ & 967 & 14.395 & $1.480(1.193-1.836)$ \\
\hline Spring & $780(82.9 \%)$ & $161(17.1 \%)$ & 941 & & $1.172(0.935-1.468)$ \\
\hline summer & $1158(85.0 \%)$ & $204(15.0 \%)$ & 1362 & & $1.122(0.835-1.868)$ \\
\hline total & $3470(82.3 \%)$ & $746(17.7 \%)$ & 4216 & $0.002 *$ & \\
\hline
\end{tabular}

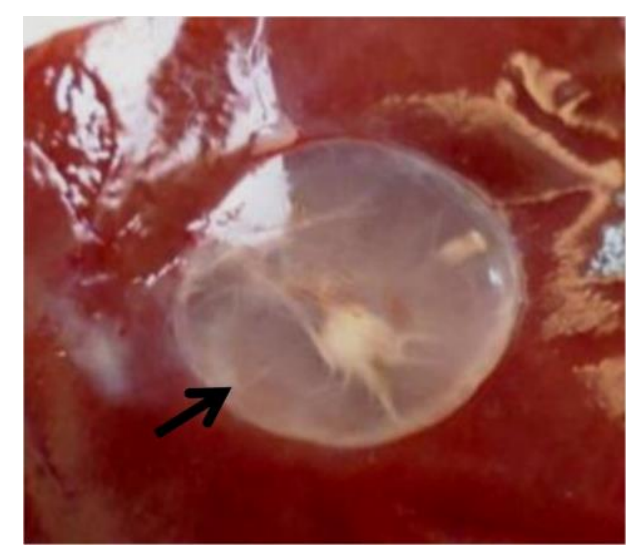

Fig. (1): C. tenuicollis attached to liver capsule of sheep, (arrow), The mean size $50 \times 65 \mathrm{~mm}$.

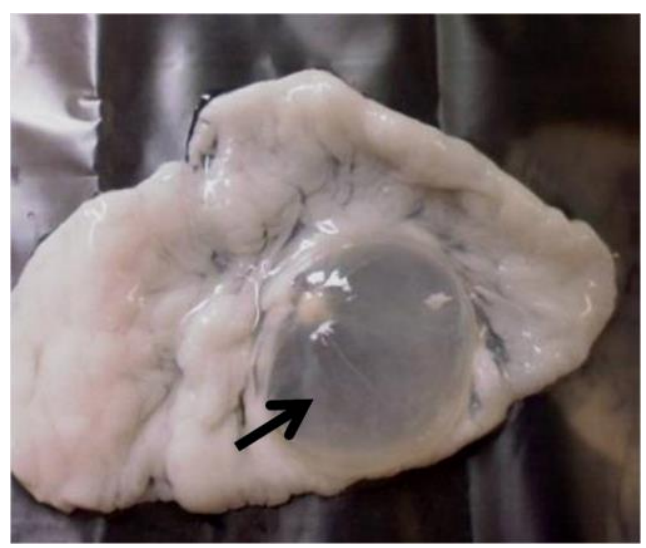

Fig. (2): C. tenuicollis attached omentun of sheep, (arrow), The mean size $50 \times 65$ $\mathrm{mm}$. 


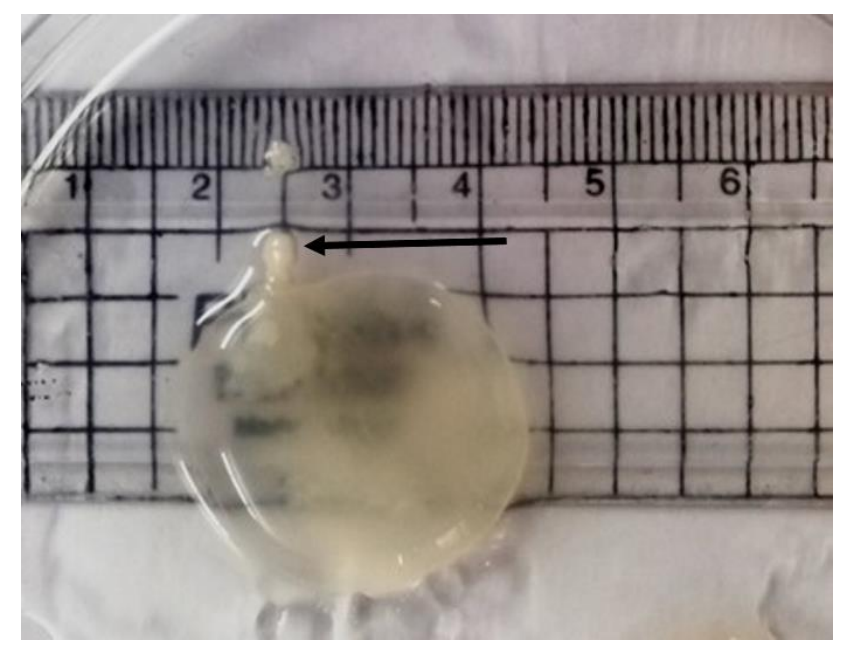

Fig. (3): Photograph of cyst showing scolex appear as white dot, (arrow).

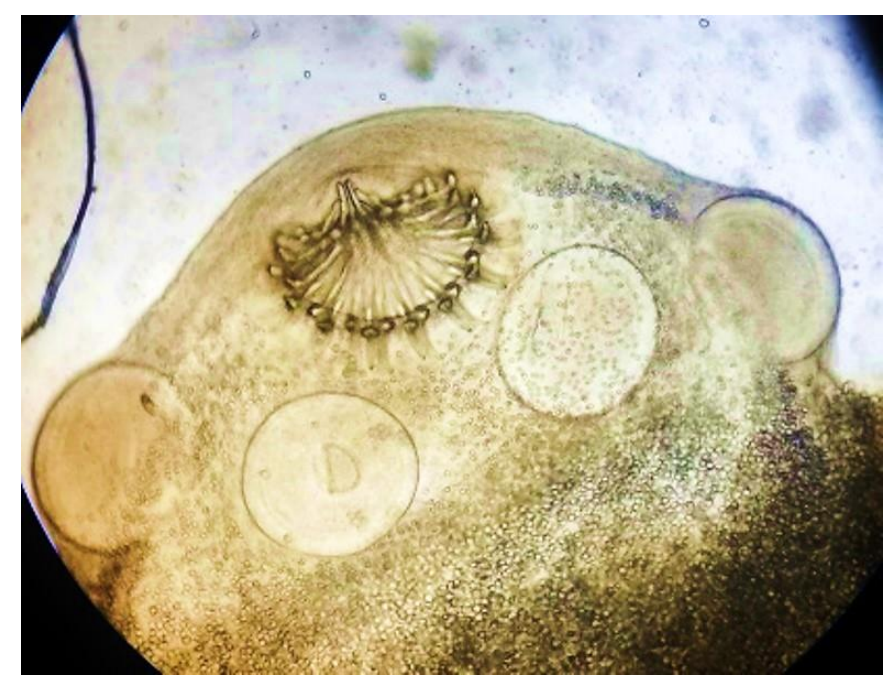

Fig. (4): Protoscolex of Cysticercus tenuicollis

\section{References}

AbouLailaa, M.; Mohamed.A.S.;

Roshdey.T; El Khatamc. A. (2020): Infection rate and biochemical characterization of Cysticercus tenuicollis from sheep in Minoufiya governorate, Egypt. Vet. Parasitol.: Regional Studies and Reports $20: 100396$.

Abu-Elwafa, S.; Al-Araby, M. and Abbas, I. (2009): Metacestodes among sheep slaughtered at Mansoura abattoir,
Dakahlia province. Egypt. Vet. Med. J. Giza 11, 21-23.

Adwan, K.; Jayousi, A.; Abuseir, S.; Abbasi, I.; Adwan, G. and Jarrar, N. (2018): Genetic diversity of Taenia hydatigena in the northern part of the West Bank, Palestine as determined by mitochondrial DNA sequences. Acta. Parasitol. 63, 299-303.

Bekele, T.; Woldeab, T.; Lahlou-Kassi, A. and Sherington, J. (1992): Factors 
affecting morbidity on-farm and on-station in the Ethiopian highland sheep. Acta. Tropica., 52, 99-109.

Blazek. K.; Schramlova. J. and Hulinska. D. (1985): Pathology of the migration phase of Taenia hydatigena (Palas 1766) larvae. Folia Parasitol. 32:127-137.

Braae. U.C.; Kabululu. M.; Nørmark. M.E.; Nejsum. P.; Ngowi. H.A. and Johansen. M.V. (2015): Taenia hydatigena cysticercosis in slaughtered pigs, goats, and sheep in Tanzania. Trop. Anim. Health. Prod. 47:1523 1530.

Dyab, A.K.; Marghany, M.E.; Osman, R.A. and Ahmed, M. (2017): Cysticercosis in small ruminants slaughtered in Aswan slaughterhouse. Egypt. Assiut. Vet. Med. J. 63, 1-8.

Eckert.J.; Gemmel. M.A.; Soulsby. E.J.L. and Matyas. Z. (1984): Guidelines for surveillance prevention and control of Echinococcosis/Hydatidosis. World Health Organization, Geneva.

El- Masry, A. A. N. (1986): Morphobiological studies on the larval stages of some cestodes. M. V. Sc. Thesis, Fac. Vet. Med., Cairo University.

El-Alfy, E.; Al-Kappany, Y.M. and Abu-Elwafa, S.A. (2017): Parasitological and pathological studies on tissue parasites among slaughtered animals in Dakahlia province. Egypt. Egypt. Vet. Med. Parasitol. Soc. J. (EVMPSJ) 13, 78-98.
El-Azazy, O. and Fayek, S. (1990): Seasonal pattern of Fasciola gigantica and Cysticercus tenuicollis infections in sheep and goats in Egypt. Bull. Anim. Health Prod. Africa 38, 369-373.

El-Dakhly, K.M.; Abo El-Hadid, S.M.; El-Askalany, M.A. and Yanai, T. (2012) An abattoir based study on Helminths of slaughtered sheep in Beni-Suef. Egypt. Beni-Suef Univ. J.Appl. Sci. 1, 49-60.

FAO (2015): Africa Sustinable Livestock 2050: Country Brief Egypt. www.fao.org/3/ai7312e.pdf.

Flisser. A.; Williams. K.; Laclette. J.P.; Larralde. C.; Ridaura. C. and Beltran. F. (1982): Cysticercosis: present state of knowledge and perspectives. Academic Press, New York.

Gånheim, C.; Fischerström, J.; Segall, T.; Christensson, D. and Uggla, A. (1998): Outbreak of cysticercosis in sheep caused by Taenia hydatigena. Svensk Veterinärtidning (Swedish Vet. J.), 50, 249-253.

Haddawee, R.; Sulbi, I. and Abass, Z. (2018): Prevalence of Cysticercus tenuicollis in slaughtered sheep and goats by season, sex, age, at Karbala abattoir. Iraq. Scientific. J. Med. Res.2, 52-56.

Kaufmann, J. (2013): Parasitic infections of domestic animals: a diagnostic manual. Birkhäuser: Birkhäuser Basel.

Mekuria, E.; Shimelis, S.; Bekele, J. and Sheferaw, D. (2013): Sheep and goats 
Cysticercus tenuicollis prevalence and associated risk factors. Afr. J. Agric. Res. 8, 3121-3125.

OIE (2008): OIE Terrestrial Manual 2008, Chap. 2.1.4. In: Echinococcosis/Hydatidosis, Paris, pp 175-189.

Omar, M.A.E.; Elmajdoub, L.O.; AlAboody, M.S.; Elsify, A.M.; Elkhtam, A.O. and Hussien, A.A. (2016): Molecular characterization of Cysticercus tenuicollis of slaughtered livestock in upper Egypt governorates. Asian Pac. J. Trop. Biomed. 6, 706-708.

Pathak, J.C.M. and Gaur, S.N. (1982): The incidence of adult and larval stage of Taenia hydatigena in Uttar Pradesh. India Veterinary Parasitology. 10:9 1-95.

Pritchard, M.H. and Kruse, G.O. (1982): The Collection and Preservation of Animal Parasites. The Harold W. Manter Laboratory, University of Nebraska Press, USA (141 pp).

Radfar, M.H.;Tajalli, S. and Jalalzadeh, M. (2005): Prevalence and morphological characterization of Cysticercus tenuicollis (Taenia hydatigena cysticerci) from sheep and goats in Iran. Vet. Arhiv 75, 469.

Samuel,W. and Zewde,G.G. (2010): Prevalence, risk factors, and distribution of Cysticercus tenuicollis in visceral organs of slaughtered sheep and goats in central Ethiopia. Trop. Anim. Health Prod. 42:1049-1051.
Scala, A.; Urrai, G.; Varcasia, A.; Nicolussi, P.; Mulas, M.; Goddi, L.; Pipia, A.P.; Sanna, G.; Genchi, M. and Bandino, E. (2016): Acute visceral cysticercosis by Taenia hydatigena in lambs and treatment with praziquantel. J. Helminthol. 90, 113-116.

Senlik, B. (2008): Influence of Host Breed, Sex and Age on the Prevalence and Intensity of $C$. tenuicollis in sheep. J. Anim. Vet. Adv. 7(5):548-551.

Singh, B.B.; Sharma, R.; Gill, J. P. S. and Sharma, J. K. (2013): Prevalence and morphological characterization of Cysticercus tenuicollis (Taenia hydatigena cysts) in sheep and goat from north India.

Sissay, M.M.; Uggla, A. and Waller, P.J. (2008): Prevalence and seasonal incidence of larval and adult cestode infections of sheep and goats in eastern Ethiopia. Trop. Anim. Health Prod. 40, 387-394.

Soulsby， E.J.L. (1982): Helminths, Arthropods and Protozoa of domesticated animals. Bailliere Tindall, London.

Soulsby, E.L. and Mönnig, H. (1982): Helminths, arthropods and protozoa of domesticated animals. 7th ed. Michigan: Bailliere Tindal \& Cassell.

SPSS Version 24.0 (2016): IBM Corp. Released 2016. IBM SPSS Statistics for Windows, Version 24.0. Armonk, NY: IBM Cor

Sultan, K.; Desoukey, A.; Elsiefy, M. and El-bahy, N. (2010): An abattoir study 
on the prevalence of some gastrointestinal helminths of sheep in Gharbia governorate. Egypt. Global. Vet. 5, 84-87.

Thompson, R.C.A. and Lymbery, A.J. (1995): Echinococcus and hydatid disease. CAB International, Wallingford.

WHO. and OIE. (2001): WHO/OIE manual on echinococcosis in humans and animals: a public health problem of global concern. France, Paris.

Wondimu, A.; Abera, D.and Hailu, Y. (2011): A study on the prevalence, distribution and economic importance of Cysticercus tenuicollis in visceral organs of small ruminants slaughtered at an abattoir in Ethiopia. J. Vet. Med. Animal Health 3, 67-74. 


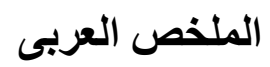

\section{في صغار المجترات Cysticercus tenuicollis تسجيل الانتشار الموسي للطور اليرقي لاول مرة في مجزر علم الروم محافظة مطروح بمصر الاتشار الموبر$$
\text { و وائل ابر اهيم فليفل' ونادية السيد لبن' }
$$$$
\text { قسم الطفيليات }
$$

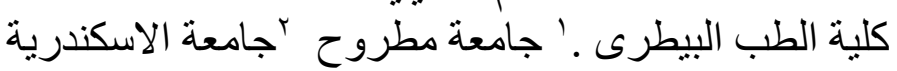

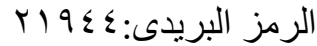

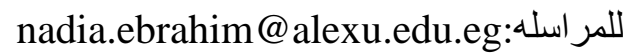

تضمنت الدر اسة عزل ونتخيص الطور اليرقي Cysticercus tenuicollis ( الكيسة المذنبة)

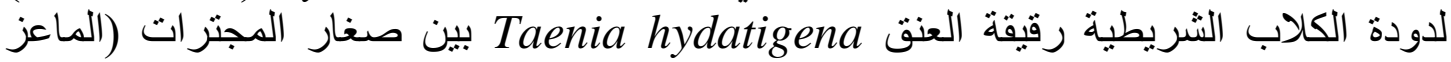

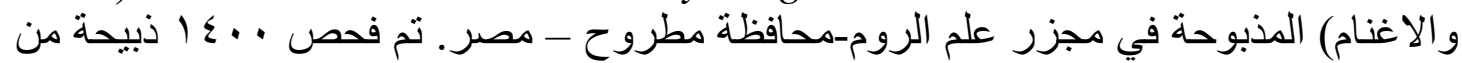

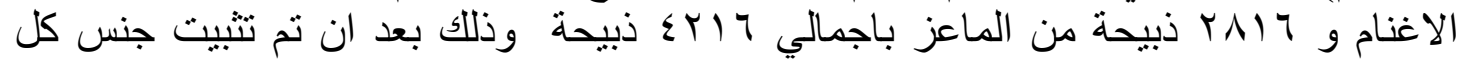

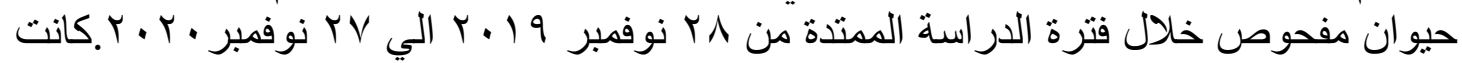

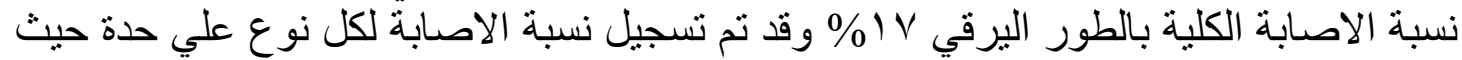

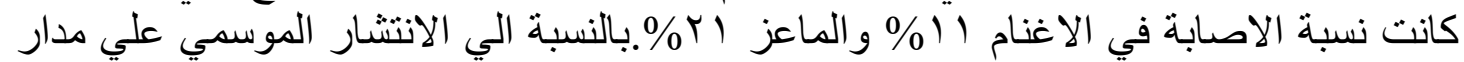

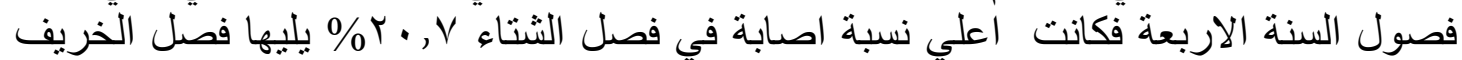

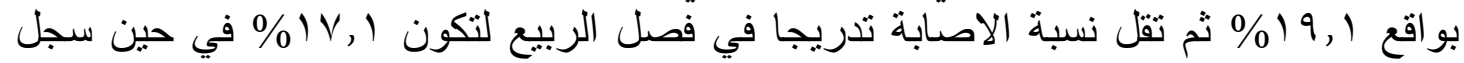

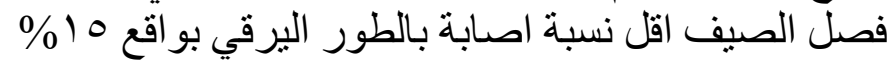

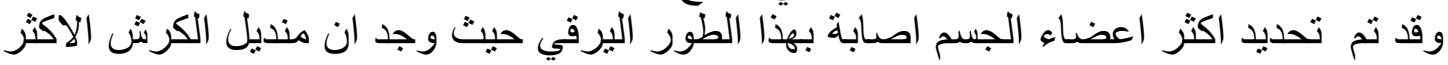

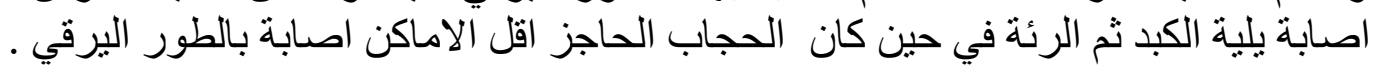

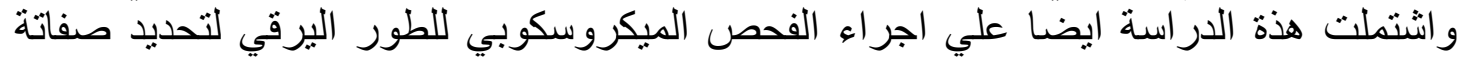

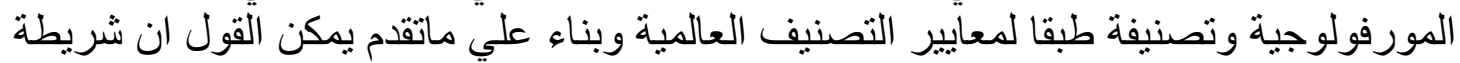

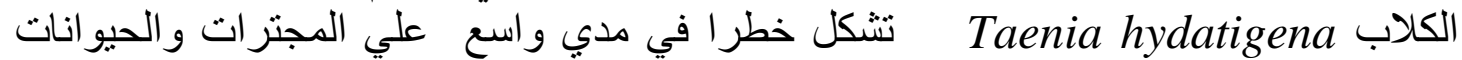

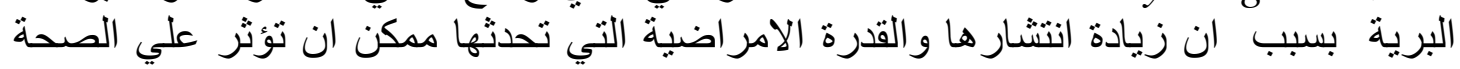

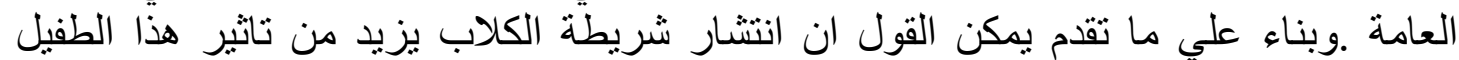

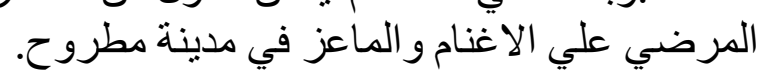

الكلمات الدالة: الطور اليرقيـ الاغنام و الماعز - شريطة الكلابـ مجزر علم الروم- مطروح 